soon and published at the end of 2011, a posthumous testimony to Melvin Hinich's continuing influence and focus on the development of a science of politics.

On the day he died, Mel sent Jones an e-mail with the classic Hinich sign-off: "Are you back in Austin? I am at home today. I teach tomorrow. Be well, Mel."

Mel never quite felt fully appreciated; perhaps because his work spanned so many fields that none of us came anywhere close to grasping it, or perhaps more likely, because he was such a poor self-promoter. He would rather fume a little and then turn to the next interesting idea. The over seventy (as of October 10) of Mel's many friends, colleagues, and students from all over the world who have shared their recollections on a website that the government department at the University of Texas has established show that indeed he was appreciated as a scholar, colleague, mentor, and human being. Please share your insights into this fascinating, complex person at http://sites.la.utexas.edu/melhinich/.

The department of government has also established the Melvin Hinich Fund to support graduate student research. Members of the UT government department have donated more than $\$ 12,500$ to this fund and have been joined by several other of Mel's friends and colleagues. Please join us in this effort. Contact Stuart Tendler (smtendler@austin.utexas. edu) for information or go to https:// utdirect.utexas.edu/nlogon/vip/ogp.WBX? menu $=\mathrm{LAGV}$. Be sure to note that the donation is for Mel Hinich and the department of government.

Mel is survived by his wife, Sonje; their daughter, Amy Leksana; and two granddaughters, Catlin and Rachel Leksana. Our condolences to them.

Michael Munger
Duke University
Peter Ordeshook
California Institute of Technology
Bryan Jones
University of Texas at Austin
Tse-min Lin
University of Texas at Austin

\section{STANLEY A. KOCHANEK}

Stanley A. Kochanek, professor emeritus of political science at the Pennsylvania State University (University Park), died May 2 of complications following heart surgery.
Professor Kochanek was born in Bayonne, New Jersey, on May 10, 1934. He inherited a strong work ethic and faith in the opportunities associated with education from his immigrant parents, who operated a bakery for many years in Bayonne. He received a bachelor's and master's degree in political science from Rutgers University. Having participated in the Army R.O.T.C. program as a student, he was commissioned as a second lieutenant in the United States Army in 1956. He completed his active duty and returned to academia at the University of Pennsylvania, where he received his Ph.D. in political science in 1963. He was appointed assistant professor of political science at Pennsylvania State University in 1963 and spent his entire career there until he retired in 2001.

Stan quickly became one of the leading experts in the field of South Asian politics. He published six books and approximately 40 articles and book chapters. His works on India, including The Congress Party of India: The Dynamic of One-Party Democracy (Princeton University Press, 1968) and Business and Politics in India (University of California Press, 1974) were groundbreaking. Both works resulted from extensive field work in India, where he interviewed numerous political and business leaders. His analyses not only employed methodology associated with area studies, but also demonstrated a keen understanding of the literature on interest groups in the United States. His article "Group Formation and Interest Group Theory" (Political Science Review, vol. 19, no. 1) attests to this grasp. In 1983, he published Interest Groups and Development: Business and Politics in Pakistan (Oxford University Press), and in 1993, he published Patron-Client Politics and Business in Bangladesh (Sage). Both of these works paralleled his earlier work in India. Stan's co-authored textbook India: Government and Politics in a Developing Nation (Harcourt Brace Jovanovich) is in its fifth edition and continues to be widely used.

Stan received numerous grants, awards, and honors during his career. Although he spent considerable time doing research in South Asia, he was also a major contributor to the welfare of his political science department at Pennsylvania State University. He was a taskmaster to his students, his colleagues, and himself, dedicated to his teaching responsibilities, and an active participant in departmental and universitywide affairs. He served admirably as departmental graduate officer both during my tenure as department head and again in later years. Stan also served effectively as acting department head during my sabbatical leave.

Stanley Kochanek, the hard worked and "hard-nosed taskmaster" was basically a "softie" who was a devoted son, husband, father, and friend. During the 40-plus years that I knew him, I admired not only his professional achievements, but also his family commitments. He did a remarkable job raising his two sons Christopher and Kevin, as a single parent during much of their childhood. I know from my conversations with him that, along with his twin brother Tony, he was also devoted to his mother until her death.

Like most of us, Stan experienced both sadness and joy in his life. But joy was an important motivator-he enjoyed good food and travel with his family. His plan to marry and embark on a new life with a lovely woman was cut short by the fatal complications of his cardiac surgery.

\section{Robert S. Friedman Pennsylvania State University}

\section{JUDITH MERKLE RILEY}

Judith Merkle Riley, longtime professor of government at Claremont McKenna College and bestselling novelist under her married name, Judith Merkle Riley, died at her home in Claremont, California, on September 12, 2010, of cancer. She was 68.

She taught under her maiden name, Judith Merkle, in the Claremont McKenna College government department from 1982 to 2005 . She joined the college, formerly Claremont Men's College, in 1982, the year after it became fully coeducational and changed its name to Claremont McKenna College. She became the department's first tenured woman member. She is remembered as one of its most consummately attentive and successful teachers. Professor Merkle was one of a small cohort of women faculty hired in the 1980 s who mentored the rapidly rising number of female undergraduates. She also championed the needs and interests of newly hired, younger female faculty. She taught organization and management, public and comparative administration, political ideologies, and health care and public policy courses.

Professor Merkle's magnum opus in political science was Management and Ideology: The Legacy of the International Scientific Management Movement (University of 